\title{
Personal Behavior Composite Data Analysis Based on Mobile Networks
}

\author{
Cheng-Hung Tsai, Zhi-Guo Zhu, Han-Wen Liu, Tsun Ku, Wu-Fan Chien \\ Institute for Information Industry, \\ Innovative DigiTech-Enabled Applications \& Service Institute, \\ Taipei, Taiwan, R.O.C. \\ \{jasontsai, louisju, tonyhwliu, cujing, juliettechien\}@iii.org.tw
}

\begin{abstract}
The paper mainly proposes the research of solving the analysis of APP operation behavior and social personal behavior preference. Through the paper put forward that the three modules implementation for data collection and analysis, which are processed according to the algorithm of each module, and its effective in the analysis of the personalized data overlapping of APP operation behavior and social network platform (Facebook). The planning of the modules presented in the paper. After the system actual verification, on the APP, the total average stay time of assignment increased by $55.96 \%$, total average bounce rate of assignment reduced $53.44 \%$, total average click through rate of assignment increased 1.1 times, total average click through rate of commodity increased 1.3 times, total average redemption rate of commodity increased 2.29 times, total average purchase rate of the commodity increased 12 times.
\end{abstract}

Keywords: Mobile Device; Social Networks; Social Persona Analysis; Cost Per Click; Personal of Interest analysis

\section{Introduction}

The value of information retained by social network can be used as one of the important source for understanding of customer opinion and behavior analysis for business owners [2]."The people" and "mobile devices" plays very important part in the social network. But also because the interaction between people derived to the operating behavior on mobile devices and the interaction between devices, so that mobile devices have become one of a method of information transmission and dissemination. And by the operation on the mobile device can be derived from the operation behavior of personal data, such as: browse the page, click behavior, stay time... and so on. Therefore, how to collect and analyze operation behavior of personal and personal social behavior (Facebook, twitter, linkedin... etc) on the mobile devices, and through the data overlapping analysis of the operation data and social persona preference data on mobile devices, which can be made to create and understand the personal preferences to achieve more significant results. Thus, how to effectively combine these two data: mobile device operating data and social platform behavior data for personal preference analysis, as the main research topic to discuss and to solve of the paper.

The framework of this paper is as follows: the first section introduces the motivation and background of this paper. The second section, through the previous research put forward that the relevant literature is discussed and analyzed. The third section introduces the used of the method and technology in the paper. The fourth section puts forward the implementation results and analysis. The fifth section is the conclusion .

\section{Related Work}

According to the estimation of the international market research authority eMarketer, the number of global users of social network has reached 1.5 billion. The number of active user of Facebook, Twitter, Weibo and Tencent were one billion, 0.5 billion and 0.3 billion at 2015[1], respectively. Furthermore, the penetration rate of social network services among the global users of all ages has reached $79 \%$. Even those once considered the main composition of digital divide has a rise of penetration rate up to $9.3 \%$. These facts show that the use of social network is very popular. The number of user of social network had a breakthrough of ten million at 2015 , according to the research of Institute for Information Industry. [9]Among those under 30 and between from 50 to 59, the proportions of using social network were $96 \%$ and $70 \%$, respectively, which show an extremely high penetration rate. As for the period of using social network, a research shows that there were more than $70 \%$ of people using it over a year. If we take those using over six months but less than a year into account, the proportion is approximately $90 \%$. Learning from the high penetration rate, the application of social network has deeply rooted in our daily life and also changed our lifestyle. 


\section{Constructing Personal Analysis}

\subsection{Data collection and analysis of APP operation}

\section{behavior in mobile devices}

In the research, we think about the user's operation behavior and characteristics of APP on mobile devices. Therefore, the research developed MORE (Multi-Object Reality Experience) SDK Console. Through we developed the SDK Tracker can be a variety of cross device APP (phone, tablet, Android, IOS) behavior data collection. APP developers only need to import Tracker SDK in the APP project, which is about to be developed. Then you can record the APP of each page under the stay time, paging type, bounce page...etc.

\section{Event Tracking Service}

Event tracking service mainly provides APP to transfer the user data and user behavior data. And take these data which transfer from APP classified as different categories to analyze. Through the Tracker module, API Tracker will store the data in the Server, and Event Tracking Service currently will record the behavior data of two kinds of APP, which are View and Event.

1) View: To record what information or commodity that the user have read, Tracker transfer PAGE parameters, PAGE refers to the current browsing page, with the PRODUCT parameter, and PRODUCT is the name of the product.

2) Event: To record what behavior that the user to do, Event: Tracker transfers TYPE parameters, behavior type data, please refer to the Table 1TYPE list (users can expand the new TYPE).

Table 1 Event Tracking Service Event Type

\begin{tabular}{|c|c|c|c|}
\hline TYPE & DESCRIPTION & TYPE & DESCRIPTION \\
\hline 0 & $\begin{array}{c}\text { Browse } \\
\text { commodity }\end{array}$ & 8 & Click bonus \\
\hline 1 & $\begin{array}{c}\text { Add commodity in } \\
\text { the shopping cart }\end{array}$ & 9 & Click gifts \\
\hline 2 & $\begin{array}{c}\text { Cancel the } \\
\text { commodity in the } \\
\text { shopping cart }\end{array}$ & 10 & $\begin{array}{c}\text { Click fare } \\
\text { purchased }\end{array}$ \\
\hline 3 & $\begin{array}{c}\text { Commodity } \\
\text { ordering }\end{array}$ & 11 & $\begin{array}{c}\text { Click clearing } \\
\text { commodity }\end{array}$ \\
\hline 4 & $\begin{array}{c}\text { Commodity } \\
\text { canceling }\end{array}$ & 12 & $\begin{array}{c}\text { Click welfare } \\
\text { commodity }\end{array}$ \\
\hline 5 & $\begin{array}{c}\text { Commodity } \\
\text { Pre-order }\end{array}$ & 13 & $\begin{array}{c}\text { Push web } \\
\text { browsing }\end{array}$ \\
\hline 6 & Commodity search & 14 & $\begin{array}{c}\text { Get serial } \\
\text { number }\end{array}$ \\
\hline 7 & Click commodity & 15 & Service \\
\hline
\end{tabular}

\subsection{Operation complexity analysis of Facebook}

\section{users}

In the research, we import the topic that we have previously studied $\lceil$ Social Persona Preference Analysis on Social Networks 」[4], we think about the operating behavior property of people on the social platform (Facebook). For example: user A is assumed to be interested in photography, user A will concern about related photography fans pages on Facebook even "join photography fans pages", and this behavior action can receive the latest photography information and satisfy the needs of user A about photography information. Another situation, user A interested in photography-related articles content, and then will "press a Like" or "share" to close friends, and these kinds of behavior patterns, all with the behavior pattern on behalf of user $A$ is an interest for photography.

But there will likely be part of the exceptional circumstances, for example: user A to part of the article is represented "agree" or "interesting" on Facebook, user A will conduct the behavior actions "press a Like" and "share" to the articles.

Through the description of the related issues above, we are thinking how to through the user behavior patterns on the social platform (Facebook), analysis of the user's exact preferences, therefore, the research on the social personal behavior pattern analysis, mainly according to the user to analyze operational complexity on Facebook, because when the operation is complex, users are willing to spend more time to obtain the relevant information services, which may represent the behavior of the most representative preferences. Therefore, the research based on the difficulty of operation setting preference weights, as shown in Table 2.

Table 2 Complexity of user operation

\begin{tabular}{|c|c|c|c|c|}
\hline $\begin{array}{c}\text { Operational } \\
\text { complexity }\end{array}$ & $\begin{array}{c}\text { Join fans } \\
\text { pages }\end{array}$ & $\begin{array}{c}\text { Press } \\
\text { like fans } \\
\text { pages }\end{array}$ & $\begin{array}{c}\text { Share } \\
\text { Article }\end{array}$ & $\begin{array}{c}\text { Press } \\
\text { like } \\
\text { article }\end{array}$ \\
\hline weight & 0.3698 & 0.3057 & 0.2721 & 0.0524 \\
\hline
\end{tabular}

According to the setting of Table 2 weight parameter value, the optimization is obtained by test $A / B$ and the process of mining adjustment, mainly based on field experiment.

\subsection{Personal preference analysis}

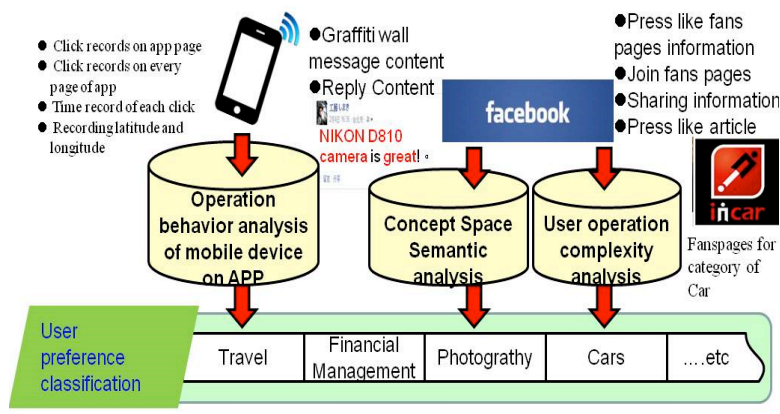

Fig. 1 Personal preference category list

Through the planning of three different using data of users, 1) Operation behavior data of user on APP, 2) The weight value of the user's operating complexity in social, 3) Concept Space semantic analysis of the user's Facebook graffiti wall. We will define a classification list of personal preferences by the behavior of users on APP and in social, as shown in Fig. 1.

Through Fig.1, we correspond to 320 Categories items on Facebook for a person's preferences in the social group. With various classification, we assume a personal favor graphy $(\mathrm{G}), \mathrm{U}, \mathrm{V}$ nodes are set to the starting point and end-point, and in accordance with 
the user on personal social behavior patterns corresponding to Facebook classification set each classified as a node. Our V denote the set of all the vertices of $G$, the edges of each graph are ordered elements formed by the two vertices. (u, v) represents from vertex $\mathrm{u}$ to $\mathrm{v}$ has connected path. Our $\mathrm{E}$ denote the set of all the edges of $\mathrm{G}$, and the weights of the edges defined by the weight function $\mathrm{w}: \mathrm{E} \rightarrow[0, \infty]$. Therefore, $\mathrm{w}(\mathrm{u}, \mathrm{v})$ is a non-negative weight right from vertex $u$ to vertex $v$. The weight of the edges can be imagined as the distance between two vertices. The weight of the path between two points is the sum of the weights of all the edges of the path.

Through the personal favor graphy, we can define the results of personal preference based on the data of each node preference, through Dijkstra's Algorithm based on the shortest path, as shown in Fig. 2, to find out the personal preference on the social group of the higher score data, can define the results of personal preference.

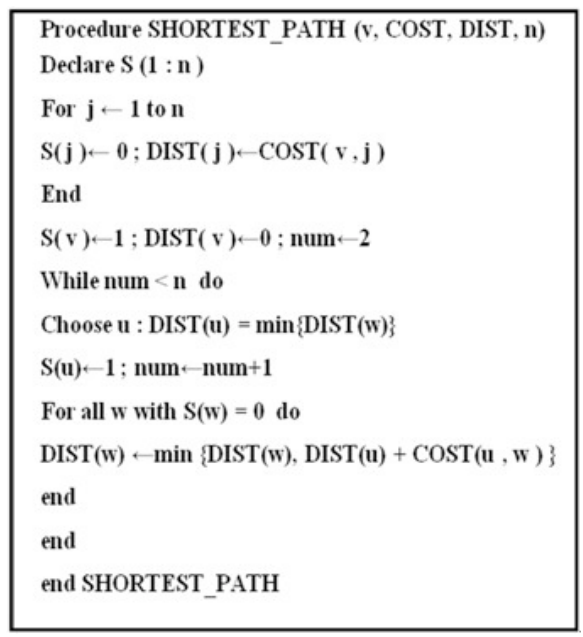

Fig. 2 Dijkstra's Algorithm

To find a vertex $\mathrm{t}$ from the $\mathrm{U}-\mathrm{V}$ set, so that the $\mathrm{D}[\mathrm{t}]$ is the minimum, and put the $\mathrm{T}$ into the $\mathrm{S}$ set, until the $\mathrm{U}-\mathrm{V}$ is empty set. Adjust the values in the D array according to the formula below:

$$
\begin{gathered}
\operatorname{Min} W(P)=\sum_{(u, v) \in P} W(u, v) \\
\mathrm{D}=\mathrm{A}[\mathrm{F}, \mathrm{I}](\mathrm{I}=1, \mathrm{~N}) \\
\mathrm{u}=\{\mathrm{F}\} \\
\mathrm{v}=\{1,2, \ldots, \mathrm{N}\} \\
\mathrm{D}[\mathrm{I}]=\min (\mathrm{D}[\mathrm{I}], \mathrm{D}[\mathrm{t}]+\mathrm{A}[\mathrm{t}, \mathrm{I} ;] \\
((\mathrm{I}, \mathrm{t}) \in \mathrm{E})
\end{gathered}
$$

$\mathrm{D}$ : An array of $\mathrm{N}$ positions for storing the shortest distance from a vertex to another vertex.

I: refers to the adjacent vertices of $\mathrm{T}$.

F: denote that starting from a starting point, $A[F, I]$ means the distance from the point $\mathrm{F}$ to point $\mathrm{I}$.

$\mathrm{v}$ : set of all node in the network.

$\mathrm{u}$ : set of vertices.

\section{Personal Behavior Analysis Based on Mobile Networks}

\subsection{System architecture}

In this section, we will introduce the details of the Persona Analysis Engine Flow Chart, as shown in the Figure 1. First, we set up Facebook Login APP on the web page, when the user login with Facebook Login APP, it will show the user's personal authorization content. And through the user click authorized personal content items, Facebook APP will deliver the user access token to the data processing platform module. Data processing platform module will conduct Facebook personal page interactive data collection by the user access token (user_profile, user_friends, user_post). With complete collection of personal data (Raw data), we will carry out three Personal preference analysis calculation module, 1.user interest 2.friend interest 3.user's post keyword mapping. Through the Persona Social analysis, we will conduct the operation data collection on APP, and take the Raw Date after being collected to conduct the module of operation behavior data analysis on APP. Its analysis of four data: 1 . Click records on app page, 2. Click records on every page of app, 3. Time record of each click, 4. Recording latitude and longitude. Finally, we'll take Social Persona preference data and APP operation behavior preference data for data overlay analysis, and generate the user preference outline. Through the type of user preferences, we conduct Recommended Engine recommendation service.

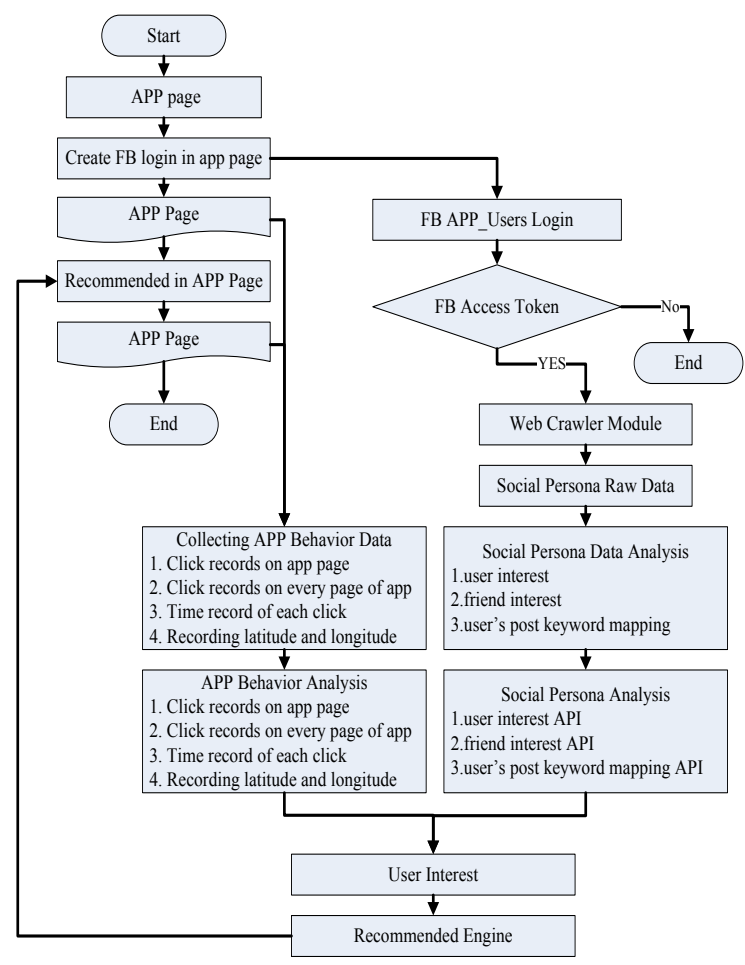

Fig.3 Architecture diagram of Persona Analysis Engine 


\subsection{System Verification}

(a) Verify field setting

The research is based on the actual field verification and planning, and the verification time range is a month, in 2016/08/01 2016/08/31, 12 categories 155 commodities, to verify user recommendation. In the paper which has collected 10,000 data of the personal preference (social \& APP) with the user's approval, through the Persona preference recommendation interface on APP. we import four kinds of recommendation services to compare, as shown in Figure 2: 1. Rule of Thumb Recommendation (ROT), 2. Social Persona preference Recommendation (SPR), 3. APP operation Behavior Recommendation (ABR), 4.Composite Data Analysis (Social \& APP) Recommendation (CDR). In the research, we compared the three recommended methods (SPR, $\mathrm{ABR}, \mathrm{CDR}$ ) with the previous ROT recommended services as follows:

Table 3 Source of commodity recommendation

\begin{tabular}{|c|c|c|c|c|}
\hline $\begin{array}{c}\text { Recommended } \\
\text { classification }\end{array}$ & food & dessert & Snacks & $\begin{array}{c}\mathrm{h} \\
\text { ealth-care } \\
\text { food }\end{array}$ \\
\hline $\begin{array}{c}\text { Commodity } \\
\text { quantity }\end{array}$ & 15 & 10 & 20 & 10 \\
\hline $\begin{array}{c}\text { Recommended } \\
\text { classification }\end{array}$ & $\begin{array}{c}\text { drug } \\
\mathrm{s}\end{array}$ & $\begin{array}{c}\text { Toy for } \\
\text { childre } \\
\mathrm{n}\end{array}$ & $\begin{array}{c}\text { Toy for } \\
\text { teens }\end{array}$ & $\begin{array}{c}\text { cleaning } \\
\text { products }\end{array}$ \\
\hline $\begin{array}{c}\text { Commodity } \\
\text { quantity }\end{array}$ & 10 & 15 & 15 & 10 \\
\hline $\begin{array}{c}\text { Recommended } \\
\text { classification }\end{array}$ & $\begin{array}{c}\text { cosm } \\
\text { etics }\end{array}$ & $\begin{array}{c}\text { skin } \\
\text { care }\end{array}$ & leisure & $\begin{array}{c}\text { daily } \\
\text { necessities }\end{array}$ \\
\hline Commodity & 10 & 10 & 10 & 20 \\
\hline quantity & & & &
\end{tabular}

(b) System statistics

The research is verified by the actual field for a month. Based on the Server back-end data which provide by the cooperation industries to verify the result of recommended technology, we will set up six index of service validation: Assignment average stay time, assignment bounce rate, assignment click through rate, commodity click through rate, commodity redemption rate, commodity purchase rate to verify. The results of the validation data are as follows:

Table 4 Rule of thumb recommendation service data

\begin{tabular}{|c|c|c|c|c|c|c|}
\hline \multirow{2}{*}{} & \multicolumn{5}{|c|}{ Rule of Thumb Recommendation (ROT) } \\
\cline { 2 - 7 } & $\begin{array}{c}\text { Assi } \\
\text { gnm } \\
\text { ent } \\
\text { aver } \\
\text { age } \\
\text { stay } \\
\text { time }\end{array}$ & $\begin{array}{c}\text { Assi } \\
\text { gnme } \\
\text { nt } \\
\text { boun } \\
\text { ce } \\
\text { rate }\end{array}$ & $\begin{array}{c}\text { Assi } \\
\text { gnm } \\
\text { ent } \\
\text { click } \\
\text { throu } \\
\text { gh } \\
\text { rate }\end{array}$ & $\begin{array}{c}\text { Comm } \\
\text { odity } \\
\text { click } \\
\text { throug } \\
\text { h rate }\end{array}$ & $\begin{array}{c}\text { Comm } \\
\text { odity } \\
\text { redemp } \\
\text { tion } \\
\text { rate }\end{array}$ & $\begin{array}{c}\text { Com } \\
\text { ty } \\
\text { purc } \\
\text { hase } \\
\text { rate }\end{array}$ \\
\hline $\begin{array}{c}\text { Tracker_- } \\
\text { A }\end{array}$ & 52.9 & $\begin{array}{c}61.7 \\
\%\end{array}$ & $\begin{array}{c}17.2 \\
\%\end{array}$ & $11.2 \%$ & $0.17 \%$ & $0 \%$ \\
\hline $\begin{array}{c}\text { Tracker_- } \\
\text { B }\end{array}$ & 61.2 & $\begin{array}{c}53.6 \\
\%\end{array}$ & $\begin{array}{c}26.1 \\
\%\end{array}$ & $12.8 \%$ & $1.2 \%$ & $\begin{array}{c}0.14 \\
\%\end{array}$ \\
\hline $\begin{array}{c}\text { Tracker_- } \\
\text { C }\end{array}$ & 58.2 & $\begin{array}{c}57.1 \\
\%\end{array}$ & $\begin{array}{c}24.9 \\
\%\end{array}$ & $12.1 \%$ & $0.9 \%$ & $0.1 \%$ \\
\hline $\begin{array}{c}\text { Tracker_ } \\
\text { D }\end{array}$ & 66.4 & $\begin{array}{c}49.8 \\
\%\end{array}$ & $\begin{array}{c}32.5 \\
\%\end{array}$ & $17.6 \%$ & $1.7 \%$ & $\begin{array}{c}0.22 \\
\%\end{array}$ \\
\hline $\begin{array}{c}\text { Tracker_ } \\
\text { E }\end{array}$ & 64.3 & $\begin{array}{c}51.4 \\
\%\end{array}$ & $\begin{array}{c}29.8 \\
\%\end{array}$ & $14.1 \%$ & $1.5 \%$ & $\begin{array}{c}0.21 \\
\%\end{array}$ \\
\hline $\begin{array}{c}\text { Tracker_ } \\
\text { F }\end{array}$ & 69.8 & $\begin{array}{c}49.3 \\
\%\end{array}$ & $\begin{array}{c}34.7 \\
\%\end{array}$ & $16.3 \%$ & $2.1 \%$ & $\begin{array}{c}0.19 \\
\%\end{array}$ \\
\hline
\end{tabular}

The research is verified by actual field, through the statistical of six recommended column data by the rule of thumb recommendation service which used by APP industries, as shown in Table 4. The total average stay time of assignment is $62.13 \mathrm{sec}$. The total average bounce rate of assignment is $53.82 \%$. The total average click through rate of assignment is $27.53 \%$. The total average click through rate of commodity is $14.01 \%$. The total average redemption rate of commodity is $1.26 \%$. The total average purchase rate is $0.14 \%$. Then, we verified and analyzed through Social Persona Preference recommendation method at follow up.

Table 5 Social Persona preference recommendation service data

\begin{tabular}{|c|c|c|c|c|c|c|}
\hline \multirow{2}{*}{} & \multicolumn{6}{|c|}{ Social Persona preference Recommendation (SPR) } \\
\cline { 2 - 7 } & $\begin{array}{c}\text { Assi } \\
\text { gnm } \\
\text { ent } \\
\text { avera } \\
\text { ge } \\
\text { stay } \\
\text { time }\end{array}$ & $\begin{array}{c}\text { Assi } \\
\text { gnm } \\
\text { ent } \\
\text { boun } \\
\text { ce } \\
\text { rate }\end{array}$ & $\begin{array}{c}\text { Assi } \\
\text { gnm } \\
\text { ent } \\
\text { click } \\
\text { throu } \\
\text { gh } \\
\text { rate }\end{array}$ & $\begin{array}{c}\text { Comm } \\
\text { odity } \\
\text { click } \\
\text { throug } \\
\text { h rate }\end{array}$ & $\begin{array}{c}\text { Comm } \\
\text { odity } \\
\text { redemp } \\
\text { tion } \\
\text { rate }\end{array}$ & $\begin{array}{c}\text { Com } \\
\text { modi } \\
\text { ty } \\
\text { purc } \\
\text { hase } \\
\text { rate }\end{array}$ \\
\hline $\begin{array}{c}\text { Tracker_ } \\
\text { A }\end{array}$ & 64.9 & $\begin{array}{c}53.2 \\
\%\end{array}$ & $\begin{array}{c}19.1 \\
\%\end{array}$ & $16.4 \%$ & $0.9 \%$ & $0.7 \%$ \\
\hline $\begin{array}{c}\text { Tracker_ } \\
\text { B }\end{array}$ & 84.4 & $\begin{array}{c}37.2 \\
\%\end{array}$ & $\begin{array}{c}34.3 \\
\%\end{array}$ & $23.9 \%$ & $2 \%$ & $1.2 \%$ \\
\hline $\begin{array}{c}\text { Tracker_ } \\
\text { C }\end{array}$ & 71.3 & $\begin{array}{c}46.2 \\
\%\end{array}$ & $\begin{array}{c}36.6 \\
\%\end{array}$ & $19.7 \%$ & $1.7 \%$ & $\begin{array}{c}1.13 \\
\%\end{array}$ \\
\hline $\begin{array}{c}\text { Tracker_- } \\
\text { D }\end{array}$ & 89.1 & $\begin{array}{c}38.6 \\
\%\end{array}$ & $\begin{array}{c}47.9 \\
\%\end{array}$ & $29.3 \%$ & $2.6 \%$ & $\begin{array}{c}1.89 \\
\%\end{array}$ \\
\hline $\begin{array}{c}\text { Tracker_ } \\
\text { E }\end{array}$ & 83.1 & $\begin{array}{c}38.3 \\
\%\end{array}$ & $\begin{array}{c}41.2 \\
\%\end{array}$ & $20.5 \%$ & $2.2 \%$ & $\begin{array}{c}1.72 \\
\%\end{array}$ \\
\hline Tracker_ \\
F
\end{tabular}

The research is verified by actual field, through the statistical of six recommended column data by Social Persona Preference recommendation service which used by APP industries, as shown in Table 5 . The total average stay time of assignment is $80.68 \mathrm{sec}$. The total average bounce rate of assignment is $41.7 \%$. The total average click through rate of assignment is $37.41 \%$. The total average click through rate of commodity is $22.27 \%$. The total average redemption rate of commodity is $2.06 \%$. The total average purchase rate is $1.46 \%$. Then, we verified and analyzed through APP operation behavior recommendation method at follow up.

Table 6 APP operation behavior recommendation service data

\begin{tabular}{|c|c|c|c|c|c|c|}
\hline \multirow{2}{*}{} & \multicolumn{2}{|c|}{ APP operation Behavior Recommendation (ABR) } \\
\cline { 2 - 7 } & $\begin{array}{c}\text { Assi } \\
\text { gnm } \\
\text { ent } \\
\text { avera } \\
\text { ge } \\
\text { stay } \\
\text { time }\end{array}$ & $\begin{array}{c}\text { Assi } \\
\text { gnm } \\
\text { ent } \\
\text { boun } \\
\text { ce } \\
\text { rate }\end{array}$ & $\begin{array}{c}\text { Assign } \\
\text { ment } \\
\text { click } \\
\text { throug } \\
\text { h rate }\end{array}$ & $\begin{array}{c}\text { Comm } \\
\text { odity } \\
\text { click } \\
\text { throug } \\
\text { h rate }\end{array}$ & $\begin{array}{c}\text { Comm } \\
\text { odity } \\
\text { redemp } \\
\text { tion } \\
\text { rate } \\
\text { modi } \\
\text { ty } \\
\text { purc } \\
\text { hase } \\
\text { rate }\end{array}$ \\
\hline $\begin{array}{c}\text { Tracke } \\
\text { r_A }\end{array}$ & 69.2 & $\begin{array}{c}47.4 \\
\%\end{array}$ & $24.8 \%$ & $15.3 \%$ & $0.7 \%$ & $0.5 \%$ \\
\hline $\begin{array}{c}\text { Tracke } \\
\text { r_B }\end{array}$ & 81.5 & $\begin{array}{c}35.8 \\
\%\end{array}$ & $38 \%$ & $20 \%$ & $1.9 \%$ & $1.1 \%$ \\
\hline $\begin{array}{c}\text { Tracke } \\
\text { r_C }\end{array}$ & 77.1 & $\begin{array}{c}38.7 \\
\%\end{array}$ & $35.8 \%$ & $18.2 \%$ & $1.6 \%$ & $\begin{array}{c}0.97 \\
\%\end{array}$ \\
\hline $\begin{array}{c}\text { Tracke } \\
\text { r_D }\end{array}$ & 94.7 & $\begin{array}{c}33.4 \\
\%\end{array}$ & $48.3 \%$ & $26.6 \%$ & $2.9 \%$ & $\begin{array}{c}1.86 \\
\%\end{array}$ \\
\hline $\begin{array}{c}\text { Tracke } \\
\text { r_E }\end{array}$ & 85.6 & $\begin{array}{c}35.4 \\
\%\end{array}$ & $44.5 \%$ & $21 \%$ & $1.9 \%$ & $\begin{array}{c}1.48 \\
\%\end{array}$ \\
\hline $\begin{array}{c}\text { Tracke } \\
\text { r_F }\end{array}$ & 92.6 & $\begin{array}{c}32.8 \\
\%\end{array}$ & $51.7 \%$ & $23.6 \%$ & $2.8 \%$ & $1.6 \%$ \\
\hline
\end{tabular}


The research is verified by actual field, through the statistical of six recommended column data by APP operating behavior recommendation service which used by APP industries, as shown in Table 6 . The total average stay time of assignment is $83.45 \mathrm{sec}$. The total average bounce rate of assignment is $37.25 \%$. The total average click through rate of assignment is $40.52 \%$. The total average click through rate of commodity is $20.7 \%$. The total average redemption rate of commodity is $1.97 \%$. The total average purchase rate is $1.25 \%$. Then, we verified and analyzed through Composite Data Analysis(Social \& APP) Recommendation (CDR) method at follow up.

Table 7 Composite Data Analysis Recommendation service data

\begin{tabular}{|c|c|c|c|c|c|c|}
\hline & \multicolumn{6}{|c|}{ Composite Data Analysis Recommendation (CDR) } \\
\hline & $\begin{array}{c}\text { Assi } \\
\text { gnm } \\
\text { ent } \\
\text { avera } \\
\text { ge } \\
\text { stay } \\
\text { time }\end{array}$ & $\begin{array}{l}\text { Assi } \\
\text { gnm } \\
\text { ent } \\
\text { boun } \\
\text { ce } \\
\text { rate }\end{array}$ & $\begin{array}{c}\text { Assign } \\
\text { ment } \\
\text { click } \\
\text { throug } \\
\text { h rate }\end{array}$ & $\begin{array}{c}\text { Comm } \\
\text { odity } \\
\text { click } \\
\text { throug } \\
\text { h rate }\end{array}$ & $\begin{array}{c}\text { Comm } \\
\text { odity } \\
\text { redemp } \\
\text { tion } \\
\text { rate }\end{array}$ & $\begin{array}{c}\text { Com } \\
\text { modi } \\
\text { ty } \\
\text { purc } \\
\text { hase } \\
\text { rate }\end{array}$ \\
\hline
\end{tabular}

QROT ISPR $\triangle \mathrm{ABR}$ 由CDR

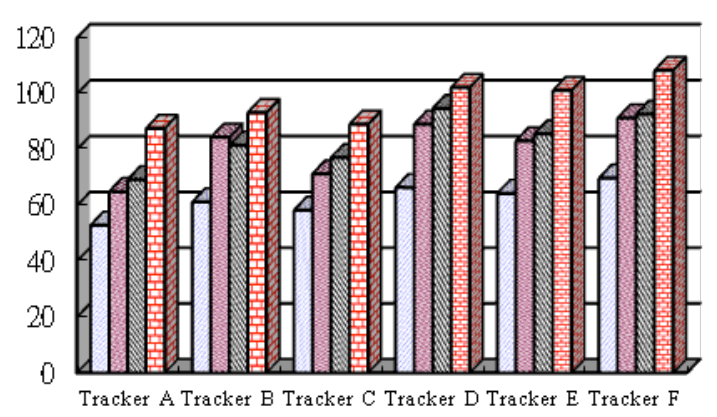

Fig. 4-1 Assignment average stay time QROT GSPR QABR GCDR

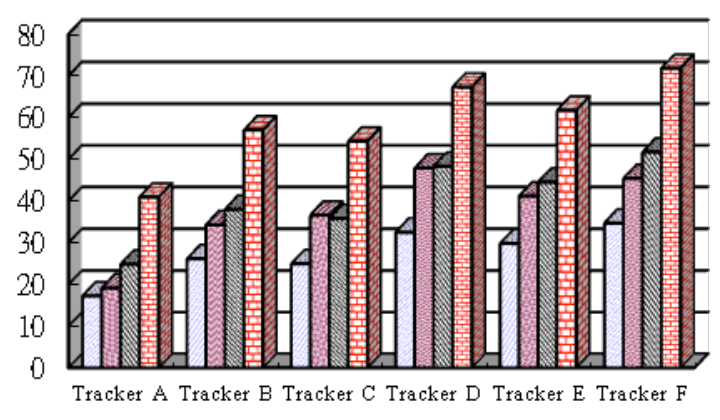

Fig. 4-3 Assignment click through rate

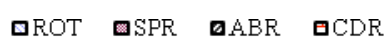

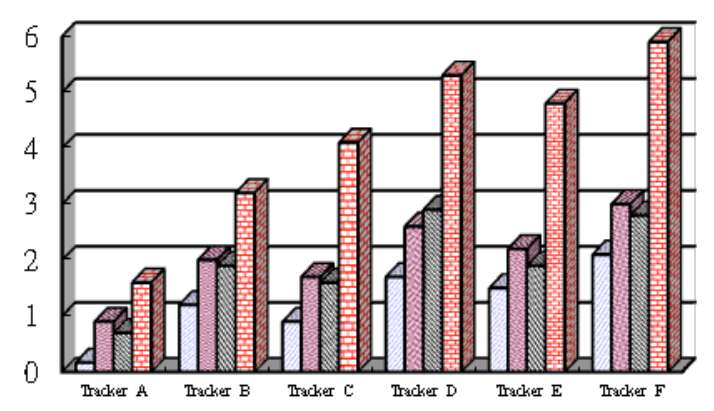

Fig. 4-5 Commodity redemption rate

\begin{tabular}{|c|c|c|c|c|c|c|}
\hline $\begin{array}{c}\text { Tracke } \\
\text { r_A }\end{array}$ & 87.6 & $\begin{array}{c}32.7 \\
\%\end{array}$ & $40.9 \%$ & $26.6 \%$ & $1.6 \%$ & $1.1 \%$ \\
\hline $\begin{array}{c}\text { Tracke } \\
\text { r B }\end{array}$ & 93.2 & $\begin{array}{c}25.2 \\
\%\end{array}$ & $57 \%$ & $32.3 \%$ & $3.2 \%$ & $1.7 \%$ \\
\hline $\begin{array}{c}\text { Tracke } \\
\text { r_C }\end{array}$ & 89 & $\begin{array}{c}26.1 \\
\%\end{array}$ & $54.3 \%$ & $29.9 \%$ & $4.1 \%$ & $1.5 \%$ \\
\hline $\begin{array}{c}\text { Tracke } \\
\text { r_D }\end{array}$ & $\begin{array}{c}102 . \\
2\end{array}$ & $\begin{array}{c}22.7 \\
\%\end{array}$ & $67.3 \%$ & $38.7 \%$ & $5.3 \%$ & $2.1 \%$ \\
\hline $\begin{array}{c}\text { Tracke } \\
\text { rEE }\end{array}$ & $\begin{array}{c}101 . \\
1\end{array}$ & $\begin{array}{c}23.4 \\
\%\end{array}$ & $61.7 \%$ & $32.4 \%$ & $4.8 \%$ & $2 \%$ \\
\hline $\begin{array}{c}\text { Tracke } \\
\text { r_F }\end{array}$ & $\begin{array}{c}108 \\
3\end{array}$ & $\begin{array}{c}20.3 \\
\%\end{array}$ & $71.8 \%$ & $36.1 \%$ & $5.9 \%$ & $\begin{array}{c}2.54 \\
\%\end{array}$ \\
\hline
\end{tabular}

The research is verified by actual field, through the statistical of six recommended column data by Composite Data Analysis Recommendation (Social \& APP) service which used by APP industries, as shown in Table 7. The total average stay time of assignment is $96.9 \mathrm{sec}$. The total average bounce rate of assignment is $25.06 \%$. The total average click through rate of assignment is $58.83 \%$. The total average click through rate of commodity is $32.67 \%$. The total average redemption rate of commodity is $4.15 \%$. The total average purchase rate is $1.82 \%$.

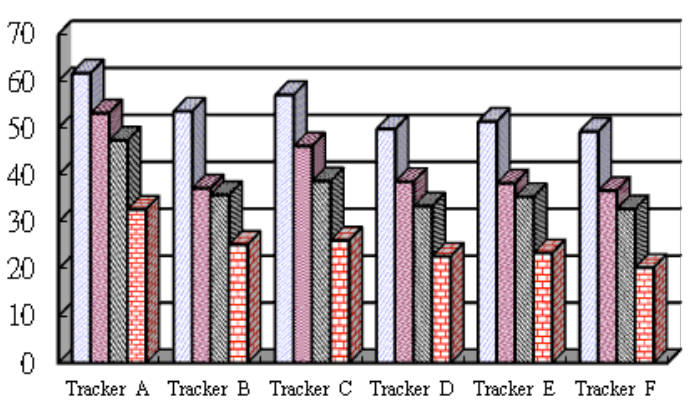

Fig. 4-2 Assignment bounce rate QROT QSPR $\square \mathrm{ABR}$ QCDR

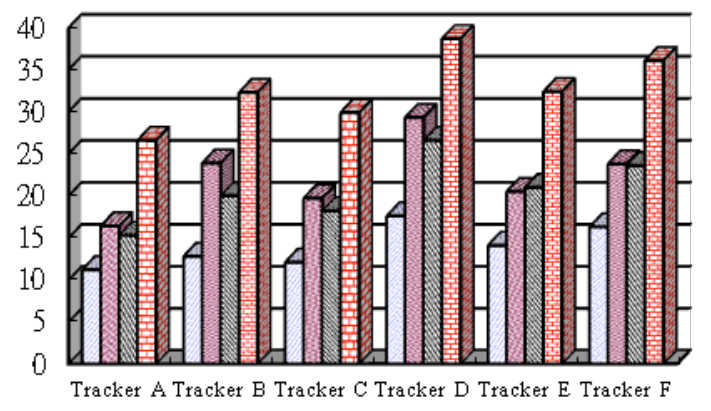

Fig. 4-4 Commodity click through rate QROT QSPR $\square \mathrm{ABR}$ QCDR

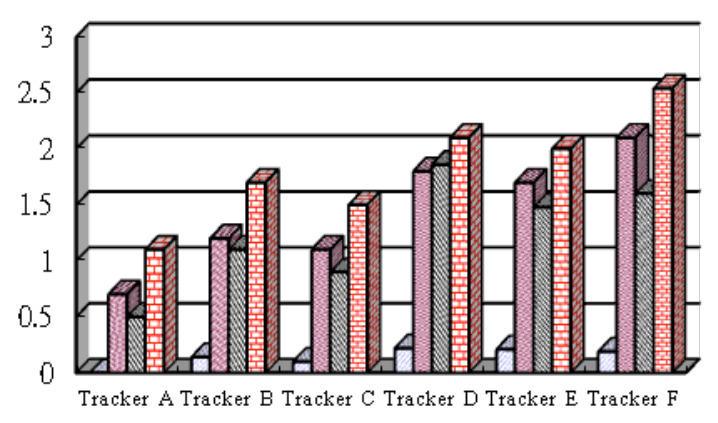

Fig. 4-6 Commodity purchase rate 
In the research, we import four kinds of recommendation services to compare, as shown in Fig 4-1 4-6: 1. Rule of Thumb Recommendation (ROT), 2. Social Persona preference Recommendation (SPR), 3. APP operation Behavior Recommendation (ABR), 4. Composite Data Analysis (Social \& APP) Recommendation (CDR), as shown in Fig. 10. In the research, we compared the three recommended methods (SPR, ABR, CDR) with the previous ROT recommended services as follows:

1) SPR V.S ROT: The total average stay time of assignments increased by $29.86 \%$, total average bounce rate of assignments reduced $22.52 \%$, total average click through rate of assignments increased $35.89 \%$, total average click through rate of commodity increased $58.96 \%$, total average redemption rate of commodity increased $63.49 \%$, total average purchase rate of the commodity increased 9.43 times.

2) ABR V.S ROT: the total average of stay time increased by $34.32 \%$, total average bounce rate of assignment reduced $30.79 \%$, total average click through rate of assignment increased $47.18 \%$, total average click through rate of commodity increased $47.75 \%$, total average redemption rate of commodity increased $56.35 \%$, total average purchase rate of the commodity increased 7.92 times.

3) CDR V.S ROT: the total average of stay time increased by $55.96 \%$, total average bounce rate of assignment reduced $53.44 \%$, total average click through rate of assignment increased 1.1 times, total average click through rate of commodity increased 1.3 times, total average redemption rate of commodity increased 2.29 times, total average purchase rate of the commodity increased 12 times.

\section{CONCLUSION}

The research is System-of-systems driven emerging service business development project (2/4) conducted by Institute for Information Industry. By our research: Persona data overlapping preference analysis based on the social mobile networks, with 10,000 user authorization acquired operation behavior data of mobile devices and personal social behavior data on Facebook. Through the two parameters of the personal preference data analysis, further analyze 10,000 personal user preference data for data overlay recommendation service: the total average of stay time increased by $55.96 \%$, total average bounce rate of assignment reduced $53.44 \%$, total average click through rate of assignment increased 1.1 times, total average click through rate of commodity increased 1.3 times, total average redemption rate of commodity increased 2.29 times, total average purchase rate of the commodity increased 12 times. Through the analysis structure of the system that planning and developing by our research, after experimentally verified and analyzed, the effectiveness of the system already has certain accuracy, and it can effectively achieve precise recommendation to enhance the contribution of the future research issue for social analysis. This is certainly one of our goals.

\section{ACKNOWLEDGEMENT}

This study is conducted under the "System-of-systems driven emerging service business development project(2/4)" of the Institute for Information Industry which is subsidized by the Ministry of Economy Affairs of the Republic of China .

\section{References}

(1) Zhang, C. ; Fang, Y.A "Trust-Based Privacy-Preserving Friend Recommendation Scheme for Online Social Networks" IEEE Transactions on Dependable and Secure Computing, ,2015, 12(4), 413-427.

(2) Louta, M.D. ; Varlamis, I. "A Trust-Aware System for Personalized User Recommendations in Social Networks", IEEE Transactions on Systems, Man, and Cybernetics,2014, 44(4), 409-421.

(3) Cheng-Hung Tsai, Tsun $\mathrm{Ku}$, and Wu-Fan Chien, "Object Architected Design and Efficient Dynamic Adjustment Mechanism of Distributed Web Crawlers", International Journal of Interdisciplinary Telecommunications and Networking,2015, 7(2), 57-71.

(4) Cheng-Hung Tsai, Han-Wen Liu, Ping-Che Yang, Tsun Ku, Wu-Fan Chien, "Social Persona Preference Analysis on Social Networks", Proceedings of IEEE ICCVE 2015.

(5) Rashid, A. "Who Am I? Analyzing Digital Personas in Cybercrime Investigations" Proceedings of IEEE Computer Magazines 46(4).

(6) Sheth, A., Thomas, C., \& Mehra, P. "Continuous semantics to analyze real-time data." Proceedings of IEEE Internet Computing, 2010,14(6), 0084-89.

(7) Cheng-Hung, Tsai, Tsun Kua, Liang-Pu Chena, Ping-che, Yang, "Constructing Concept Space from Social Collaborative Editing," Proceedings of AHFE 2015.

(8) Hui Zheng; Ji-kun Yan; Ye Jin "Persona Analysis with Text Topic Modelling" Proceedings of IEEE ACAI 2012.

(9) Cheng-Hung Tsai, Han-Wen Liu, Tsun $\mathrm{Ku}$, Wu-Fan Chien, "Personal Preferences Analysis of User Interaction based on Social Networks", IEEE ICCCS 2015.

(10)Shiga, A., “A Support System for Making Persona Using Bayesian Network Analysis" Proceedings of IEEE ICBAKE 2013. 